\title{
Effect of $\omega-3$ polyunsaturated fatty acids on the growth of IEC-6 cells injured by heavy metals
}

\author{
FENG ZHANG ${ }^{1}$, HAINING YU ${ }^{2}$, XIAOFENG NI ${ }^{3}$, JING ZHU $^{2}$, SHANSHAN WANG $^{3}$ and SHENGRONG SHEN $^{3}$ \\ ${ }^{1}$ Department of Stomatology, Children's Hospital, School of Medicine, Zhejiang University, Hangzhou, \\ Zhejiang 310003; ${ }^{2}$ College of Pharmaceutical Science, Zhejiang University of Technology, Hangzhou, Zhejiang 310032; \\ ${ }^{3}$ School of Biosystems Engineering and Food Science, Zhejiang University, Hangzhou, Zhejiang 310058, P.R. China
}

Received December 15, 2015; Accepted February 24, 2016

DOI: $10.3892 / \mathrm{br} .2016 .621$

\begin{abstract}
Environmental pollution is a current area of focus worldwide, particularly heavy metal pollution. Feasible prevention or therapeutic strategies are required. Exploration of the correlation between $\omega-3$ polyunsaturated fatty acids ( $\omega-3$ PUFAs) and intestinal epithelial cells injured by heavy metals may be of significance for intestinal health. In the present study, the effects of $\omega-3$ PUFAs on the rat intestinal crypt cell line (IEC-6) injured by heavy metals and its mechanisms were determined according to the evaluation of cell viability and expression levels of reactive oxygen species (ROS), epidermal growth factor (EGF) and interleukin-6 (IL-6). The results demonstrated that $\omega-3$ PUFAs can improve the viability of IEC- 6 cells injured by heavy metals and the expression level of ROS was correlated with oxidative damage; the increased expression level of inflammatory factors is associated with cell apoptosis. In the present study, $\omega-3$ PUFAs significantly decreased the expression levels of ROS, EGF and IL-6. This indicates that the protective action of $\omega-3$ PUFAs was associated with a decrease of oxidative damage and pro-inflammatory cytokine expression against the damage of heavy metals.
\end{abstract}

\section{Introduction}

Environmental pollution and food safety problems are becoming increasingly serious and are directly threatening human health. In particular, the effect and mechanism of heavy metal pollution on health has received increasing attention from investigators worldwide. Heavy metals have toxic effects on the whole body system, particularly on the nerve, blood, digestive tract, heart, kidney and immune systems; they enter the body through ingestion (1-3). Intestinal epithelial cells are a major medium between the internal and external

Correspondence to: Professor Shengrong Shen, School of Biosystems Engineering and Food Science, Zhejiang University, 866 Yuhangtang Road, Hangzhou, Zhejiang 310058, P.R. China E-mail: shrshen@zju.edu.cn

Key words: $\omega-3$ PUFAs, heavy metals, intestinal crypt cell line, oxidative damage environment; and are also the frontline of the defensive system to resist the invasion of exotic pathogens.

Previous studies have shown that $\omega-3$ polyunsaturated fatty acids ( $\omega-3$ PUFAs), such as eicosapentaenoic acid (EPA; C20:5, $\omega 3$ ) and docosahexaenoic acid (DHA; C22:6, $\omega 3$ ), contributed to preventing or reducing the incidence of peptic ulcer disease and obesity (4-6), and improving the prognosis of several chronic inflammatory diseases, including atherosclerosis, systemic lupus erythematosus, psoriasis, inflammatory bowel disease and rheumatoid arthritis (7-10). The anti-inflammatory characteristics of $\omega-3$ PUFAs, including decreasing cyclooxygenase-2 expression and cytokines, are consistent in numerous studies (11-13) and evidence the hypothesis that inhibition of inflammatory responses may be a viable protective strategy against heavy metal damage.

In order to understand the effects of $\omega-3$ PUFAs on intestinal crypt (IEC-6) cells injured by heavy metals, the present study investigated the effect of EPA and DHA on the viability of heavy metal-injured IEC-6 cells and the expression levels of reactive oxygen species (ROS), epidermal growth factor (EGF) and interleukin-6 (IL-6).

\section{Materials and methods}

Materials. High-glucose Dulbecco's modified Eagle's medium (DMEM) and trypsin were obtained from Gino Biomedical Technology Co., Ltd. (Hangzhou, China). Fetal bovine serum was purchased from Invitrogen Life Technologies (Carlsbad, CA, USA). Rat intestinal crypt cells (IEC-6) were from the American Type Culture Collection (Manassas, VA, USA). EPA, DHA and dimethylsulphoxide (DMSO) were from Sigma-Aldrich (St. Louis, MO, USA), and all other chemicals were of analytical grade.

Cell culture. IEC- 6 cells were cultured in high-glucose DMEM supplemented with $10 \%$ heat-inactivated fetal bovine serum (at $\mathrm{pH} 7.2$ ), and placed in a $5 \% \mathrm{CO}_{2}$-humidified incubator at $37^{\circ} \mathrm{C}$. The culture medium was replaced every 48 h. $\mathrm{CuSO}_{4}, \mathrm{CrCl}_{3}$ and $\mathrm{Pb}\left(\mathrm{CH}_{3} \mathrm{COO}\right)_{2} \cdot 3 \mathrm{H}_{2} \mathrm{O}$ were dissolved in high-purity water at a concentration of $100 \mathrm{mmol} / \mathrm{l}$ as a stock solution, and was filtered prior to use. Stock solutions (20 mmol/l) of EPA and DHA were prepared in anhydrous ethanol, respectively, and diluted with sterile water prior to use. 

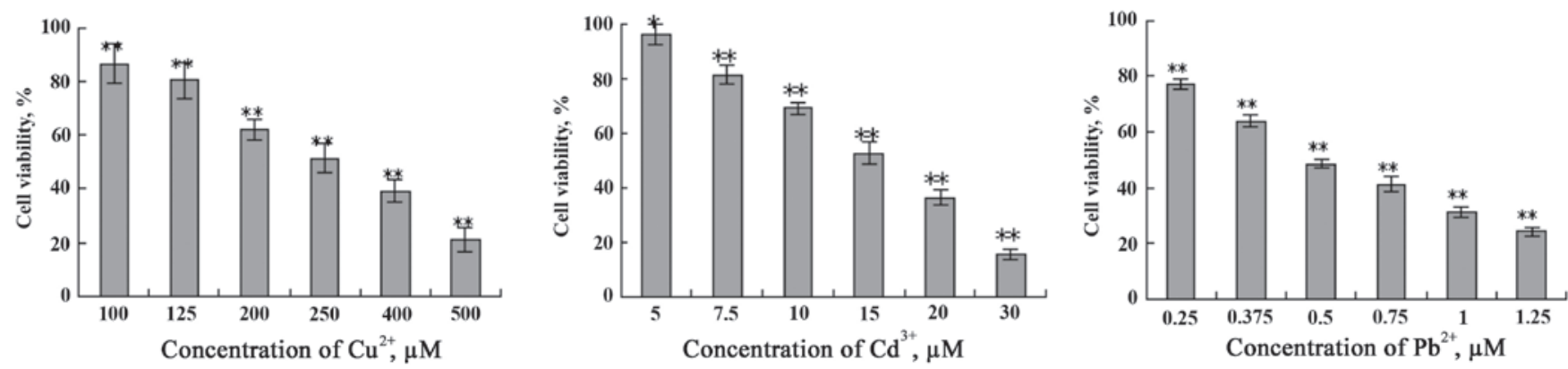

Figure 1. Effect of heavy metal ions $\left(\mathrm{Cu}^{2+}, \mathrm{Cd}^{3+}\right.$ and $\left.\mathrm{Pb}^{2+}\right)$ at different concentrations on the viability of IEC-6 cells. ${ }^{*} \mathrm{P}<0.05 ;{ }^{* * *} \mathrm{P}<0.01$.
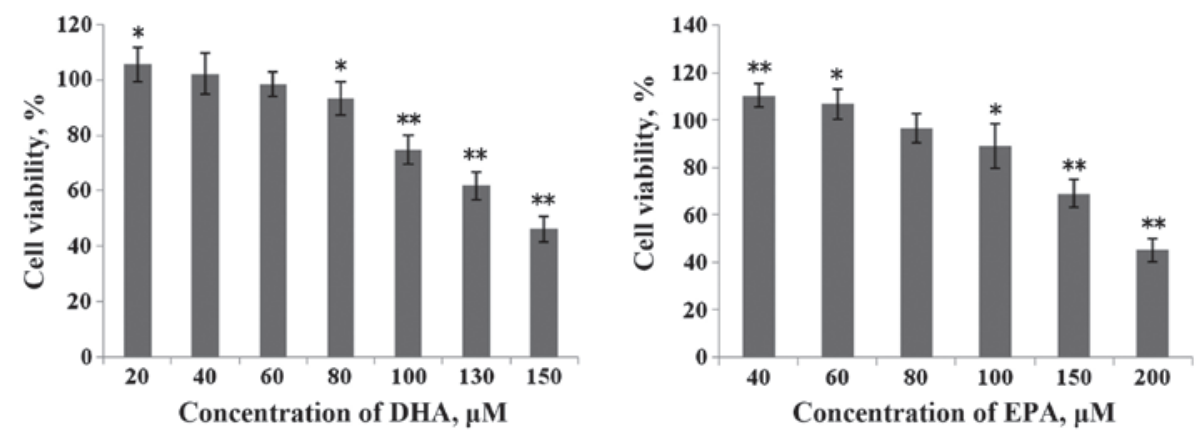

Figure 2. Effect of $\omega-3$ polyunsaturated fatty acids (DHA and EPA) at different concentrations on the viability of IEC-6 cells. " $\mathrm{P}<0.05 ;{ }^{* *} \mathrm{P}<0.01$. DHA, docosahexaenoic acid; EPA, eicosapentaenoic acid.

MTT assay. The IEC-6 cells in the logarithmic growth period were seeded in 96-well plates at a density of $10^{4}$ cells/well. After 4-h culture, the cells were treated with $10 \mu \mathrm{l}$ of different concentrations of DHA, EPA and metal ions $\left(\mathrm{Cu}^{2+}, \mathrm{Cd}^{3+}\right.$ and $\left.\mathrm{Pb}^{2+}\right)$ and maintained for $48 \mathrm{~h}$. Following this, $20 \mu \mathrm{l}$ of MTT solution $(5 \mathrm{mg} / \mathrm{ml})$ was supplemented at the end of the incubation period. Cells were incubated for another $3 \mathrm{~h}$ at $37^{\circ} \mathrm{C}$ before being removed from the cultured medium. Subsequently, $150 \mu 1$ of DMSO was added to each well, and the formazan crystals were dissolved on a horizontal oscillator. The optical density was detected at the $570 \mathrm{~nm}$ wavelength by an ELISA microplate reader and cell viability was calculated as follows.

Cell viability $=\frac{\text { experimental group OD }- \text { zero group OD }}{\text { control group OD }- \text { blank group OD }} \times 100 \%$

By contrast, the effect of preincubation with $10 \mu \mathrm{l}$ of different concentrations of metal ions for $1 \mathrm{~h}$ followed by further exposure to various doses of DHA and EPA was investigated.

ROS, EGF and IL-6 measurement. IEC-6 cells were seeded in 96 -well plates at a density of $2 \times 10^{5}$ cells/well. Subsequently, heavy metal-exposed IEC- 6 cells were treated with $\omega-3$ PUFAs. Subsequently, IEC-6 cells and culture medium were collected for the measurement of ROS, EGF and IL-6 using the $\mathrm{LXA}_{4}$ ELISA kit, according to the manufacturer's protocol (Shanghai Lianshuo Biological Technology Co., Ltd., Shanghai, China). The results were corrected by the protein level based on the reference manual of the bicinchoninic acid protein assay kit (Shanghai Beyotime Biotechnology, Shanghai, China).
Statistical analysis. All the data are expressed as mean \pm standard deviation, and was analyzed using SPSS 13.0 software (SPSS, Inc., Chicago, IL, USA). Significant differences of analyses between varying groups were analyzed by analysis of variance.

\section{Results}

Effect of heavy metal $\left(\mathrm{Cu}^{2+}, \mathrm{Cd}^{3+}\right.$ and $\left.\mathrm{Pb}^{2+}\right)$ and $\omega-3$ PUFA treatments on cell viability. In the present study, to evaluate the damage effect of heavy metals $\left(\mathrm{Cu}^{2+}, \mathrm{Cd}^{3+}\right.$ and $\left.\mathrm{Pb}^{2+}\right)$ on IEC-6 cells, cell viability was detected by the MTT assay. Supplementation of $\mathrm{Cu}^{2+}(100-500 \mu \mathrm{M}), \mathrm{Cd}^{3+}(5-30 \mu \mathrm{M})$ and $\mathrm{Pb}^{2+}(0.25-1.5 \mathrm{mM})$ to the IEC-6 cells resulted in a significant dose-dependent decrease in cell viability when compared with the control group (Fig. 1). According to the demonstrated results, concentrations of 500,250 and $125 \mu \mathrm{M}$ of $\mathrm{Cu}^{2+}$ with 30 and $15 \mu \mathrm{M}$ of $\mathrm{Cd}^{3+}$, and $7.5 \mu \mathrm{M}$ of $\mathrm{Cd}^{3+}$ with 1 , 0.5 and $0.25 \mathrm{mM}$ of $\mathrm{Pb}^{2+}$ were chosen for the subsequent experiments. Similarly, IEC-6 cells were incubated with DHA, ranging from 20 to $150 \mu \mathrm{M}$ and EPA from 40 to $200 \mu \mathrm{M}$ for $48 \mathrm{~h}$, respectively. Simultaneously with the increase of concentration, cell viability decreased gradually (Fig. 2). According to these results, $60 \mu \mathrm{M}$ DHA and $80 \mu \mathrm{M}$ EPA were chosen for the subsequent experiments, as they exhibited no significant effect on IEC-6 cell viability.

Effects of DHA and EPA on viability of IEC-6 cells injured by $C u^{2+}$. In order to study the effect of $\omega-3$ PUFAs on IEC- 6 cells injured by heavy metals, the IEC- 6 cell culture was supplemented with the two $\omega-3$ PUFAs and a metal ion. Following 

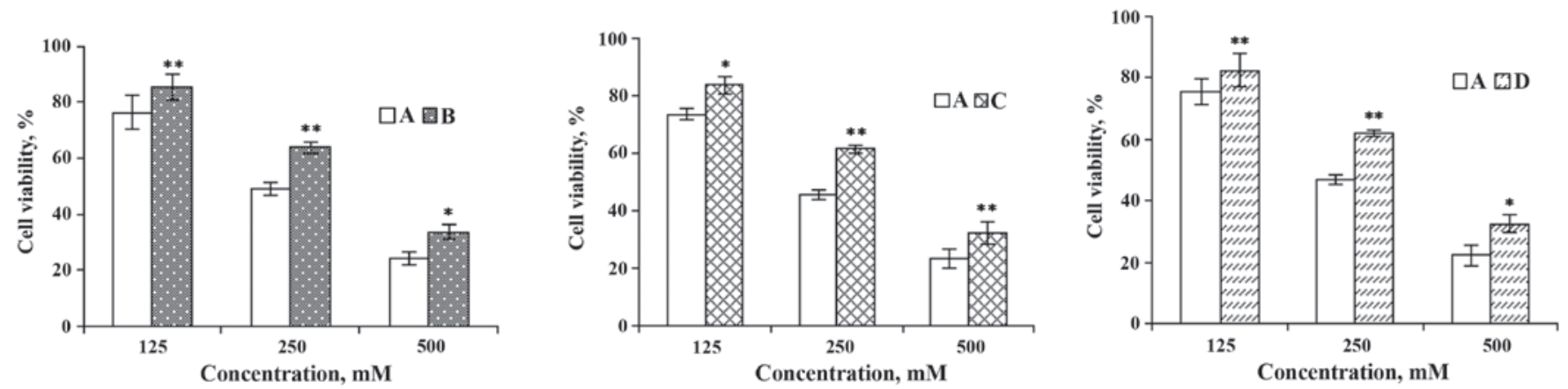

Figure 3. Effects of DHA on IEC-6 cells injured by $\mathrm{Cu}^{2+}$. (A) $\mathrm{Cu}^{2+}$-injured; (B) $\mathrm{Cu}^{2+}$-injured and subsequently repaired by DHA; (C) DHA treatment followed by $\mathrm{Cu}^{2+}$-injury; and (D) simultaneous addition of $\mathrm{Cu}^{2+}$ and DHA. ${ }^{*} \mathrm{P}<0.05 ;{ }^{* *} \mathrm{P}<0.01$. DHA, docosahexaenoic acid.
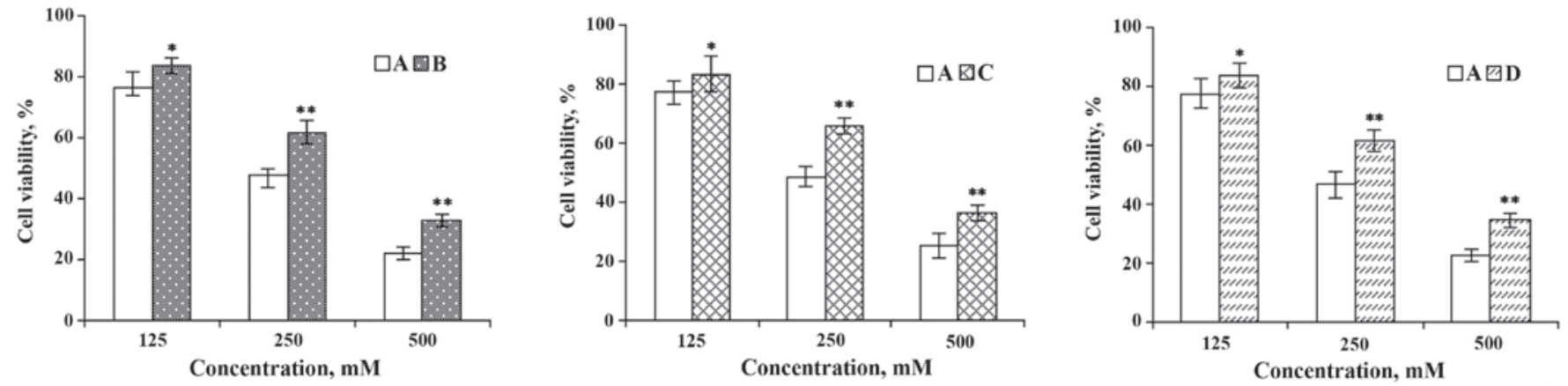

Figure 4. Effects of EPA on IEC-6 cells injured by $\mathrm{Cu}^{2+}$. (A) $\mathrm{Cu}^{2+}$-injured; (B) $\mathrm{Cu}^{2+}$ injured and subsequently repaired by EPA; (C) EPA treatment followed by $\mathrm{Cu}^{2+}$-injury; and (D) simultaneous addition of $\mathrm{Cu}^{2+}$ and EPA. ${ }^{2} \mathrm{P}<0.05 ;{ }^{* *} \mathrm{P}<0.01$. EPA, eicosapentaenoic acid.
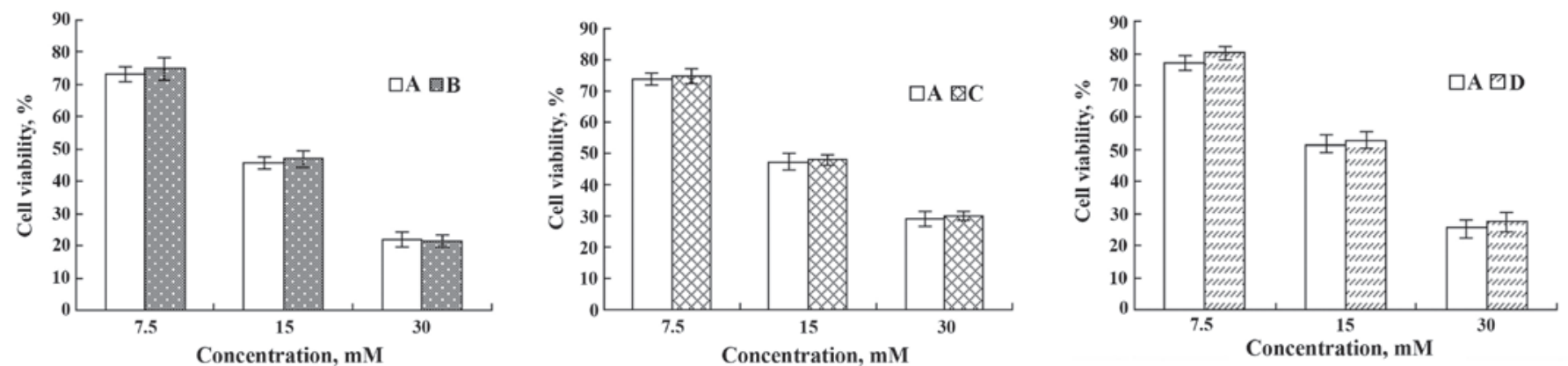

Figure 5. Effects of DHA on IEC-6 cells injured by $\mathrm{Cd}^{3+}$. (A) $\mathrm{Cd}^{3+}$-injured; (B) $\mathrm{Cd}^{3+}$ injured and subsequently repaired by DHA; (C) DHA treatment followed by $\mathrm{Cd}^{3+}$-injury; and (D) simultaneous addition of $\mathrm{Cd}^{3+}$ and DHA. DHA, docosahexaenoic acid.

pre-incubation of cells with $250 \mu \mathrm{M}$ of $\mathrm{Cu}^{2+}$ for $1 \mathrm{~h}$ followed by further exposure to various doses of DHA and EPA, cell viability increased 14.78 and $14.29 \%$, respectively (Figs. 3 and 4). By contrast, pre-incubation of cells with $10 \mu \mathrm{l}$ DHA and EPA for $1 \mathrm{~h}$ prior to an addition of $250 \mu \mathrm{M} \mathrm{Cu}^{2+}$, the cell viability was enhanced 15.83 and 16.94\%, respectively (Figs. 3 and 4). Furthermore, while DHA or EPA with $250 \mu \mathrm{M}$ of $\mathrm{Cu}^{2+}$ were treated simultaneously, IEC-6 viable cells were increased by 15.05 and $14.74 \%$ (Figs. 3 and 4). These results enable us to conclude that DHA and EPA could significantly improve the cell viability of IEC- 6 cells despite being inflicted by $\mathrm{Cu}^{2+}$.

Effects of DHA and EPA on the viability of IEC-6 cells injured by $\mathrm{Cd}^{3+}$. The protective effect on the IEC- 6 cells following DHA, EPA and $\mathrm{Cd}^{3+}$ exposure was also investigated.
DHA was shown to have no significant effect on the $15 \mu \mathrm{M}$ $\mathrm{Cd}^{3+}$-injured IEC-6 cells (Fig. 5). By contrast, EPA had a significant effect on the cell viability, with increases of 18.59, 16.88 and $19.71 \%$, respectively (Fig. 6). Therefore EPA, but not DHA, has a protective effect on the IEC- 6 cells injured by $\mathrm{Cd}^{3+}$.

Effects of DHA and EPA on viability of IEC-6 cells injured

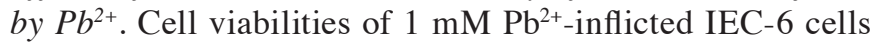
increased to 10.16 and $7.65 \%$ following treatment with DHA and EPA (Figs. 7 and 8). Additionally, the cell viabilities were enhanced by 20.73 and $9.76 \%$, respectively, as cells were pre-incubated with $10 \mu \mathrm{l}$ DHA and EPA for $1 \mathrm{~h}$ prior to supplementation with $1 \mathrm{mM}$ of $\mathrm{Pb}^{2+}$ (Figs. 7 and 8). When the cells were simultaneously treated with DHA or EPA and 

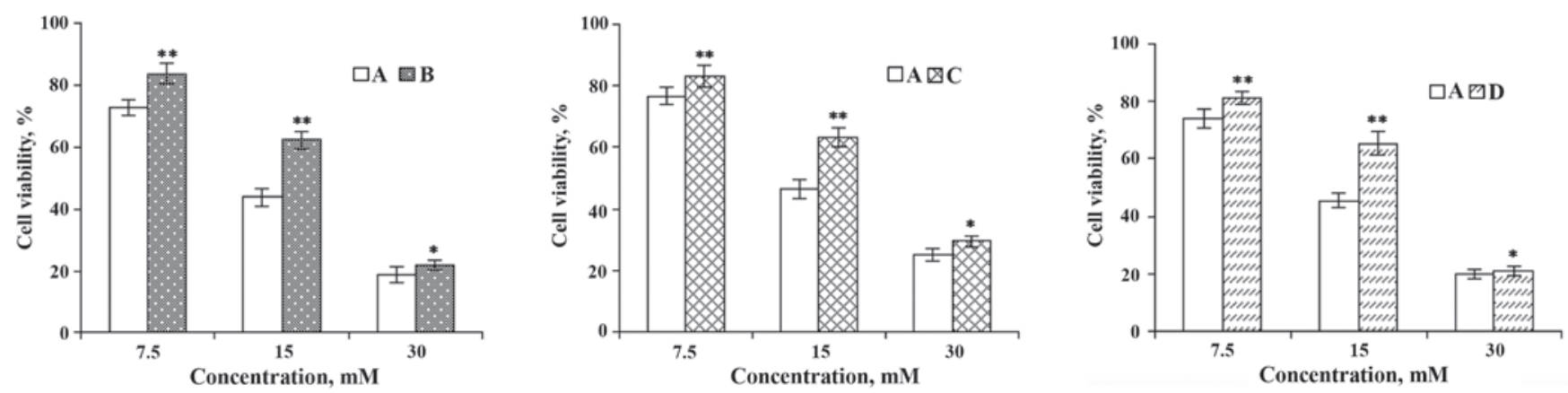

Figure 6. Effects of EPA on IEC-6 cells injured by $\mathrm{Cd}^{3+}$. (A) $\mathrm{Cd}^{3+}$-injured; (B) $\mathrm{Cd}^{3+}$ injured and subsequently repaired by EPA; (C) EPA treatment followed by $\mathrm{Cd}^{3+}$-injury; and (D) simultaneous addition of $\mathrm{Cd}^{3+}$ and EPA. ${ }^{*} \mathrm{P}<0.05 ;{ }^{* *} \mathrm{P}<0.01$. EPA, eicosapentaenoic acid.
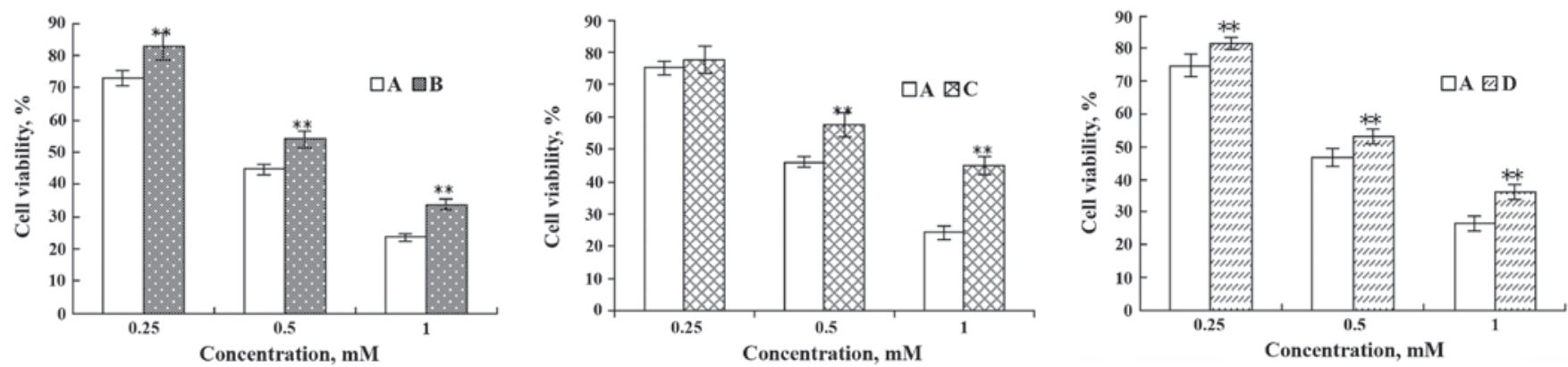

Figure 7. Effects of DHA on IEC-6 cells injured by $\mathrm{Pb}^{2+}$. (A) $\mathrm{Pb}^{2+}$-injured; (B) $\mathrm{Pb}^{2+}$ injured and subsequently repaired by DHA; (C) DHA treatment followed by $\mathrm{Pb}^{2+}$-injury; and (D) simultaneous addition of $\mathrm{Pb}^{2+}$ and $\mathrm{DHA} .{ }^{* *} \mathrm{P}<0.01$. DHA, docosahexaenoic acid.
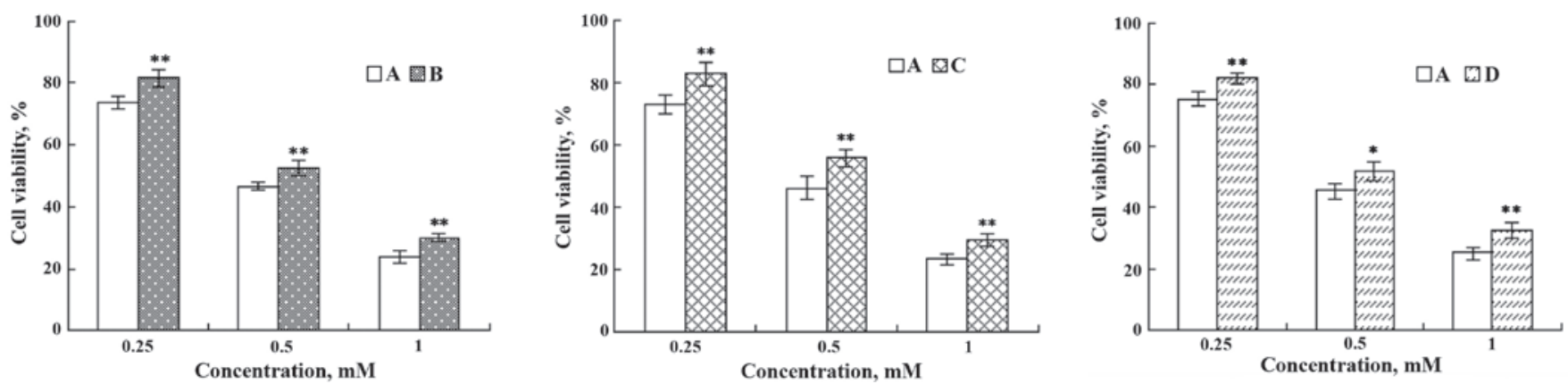

Figure 8. Effects of EPA on IEC-6 cells injured by $\mathrm{Pb}^{2+}$. (A) $\mathrm{Pb}^{2+}$-injured; (B) $\mathrm{Pb}^{2+}$ injured and subsequently repaired by EPA; (C) EPA treatment followed by $\mathrm{Pb}^{2+}$-injury; and (D) simultaneous addition of $\mathrm{Pb}^{2+}$ and EPA. ${ }^{* *} \mathrm{P}<0.01$. EPA, eicosapentaenoic acid.

$1 \mathrm{mM}$ of $\mathrm{Pb}^{2+}$, the cell viabilities were observed to increase by 9.83 and $7.08 \%$, respectively (Figs. 7 and 8 ).

Effects of DHA and EPA on the ROS, EGF and IL-6 levels of IEC- 6 cells injured by $\mathrm{Cu}^{2+}$. The IEC- 6 cell lines were exposed to various concentrations of DHA or EPA and $\mathrm{Cu}^{2+}$. After $48 \mathrm{~h}$, the levels of ROS, EGF and IL-6 secreted by IEC- 6 cells were detected. The amounts of ROS, EGF and IL-6 generated by the IEC-6 cells incubated with $\mathrm{Cu}^{2+}$ were significantly higher in comparison with the untreated control $\left({ }^{* *} \mathrm{P}<0.01\right)$. By contrast, incubation of the IEC-6 cells with DHA and EPA resulted in a substantial decrease of the IL-6 level when compared with the control group ( $\mathrm{P}>0.05)$ (Figs. 9 and 10). Regardless of the additional sequence of DHA or EPA and $\mathrm{Cu}^{2+}$, DHA and EPA significantly reduced the expression levels of ROS, EGF and
IL-6 in the IEC-6 cells $\left({ }^{* *} \mathrm{P}<0.01 ;{ }^{*} \mathrm{P}<0.05\right)$ (Figs. 9 and 10 ). Therefore, DHA and EPA had a protective effect on the IEC-6 cells damaged by $\mathrm{Cu}^{2+}$ by reducing the expression levels of ROS, EGF and IL-6.

Effects of DHA and EPA on ROS, EGF and IL-6 levels of IEC- 6 cells injured by $\mathrm{Cd}^{3+}$. Similarly, incubation of IEC-6 cells with DHA and EPA for $48 \mathrm{~h}$ induced no significant variation in the secretion of ROS, EGF and IL-6; however, the level of ROS, EGF and IL-6 substantially increased after treatment of $\mathrm{Cd}^{3+}$ (Figs. 11 and 12). DHA treatment exhibited changes in the secretion level of ROS, EGF and IL- 6 in the $\mathrm{Cd}^{3+}$-injured IEC-6 cells (Fig. 11). Notably, when IEC-6 cells were supplemented with EPA, as shown in Fig. 12, there was an evident reduction in the secretion of ROS, EGF and IL-6 levels. 

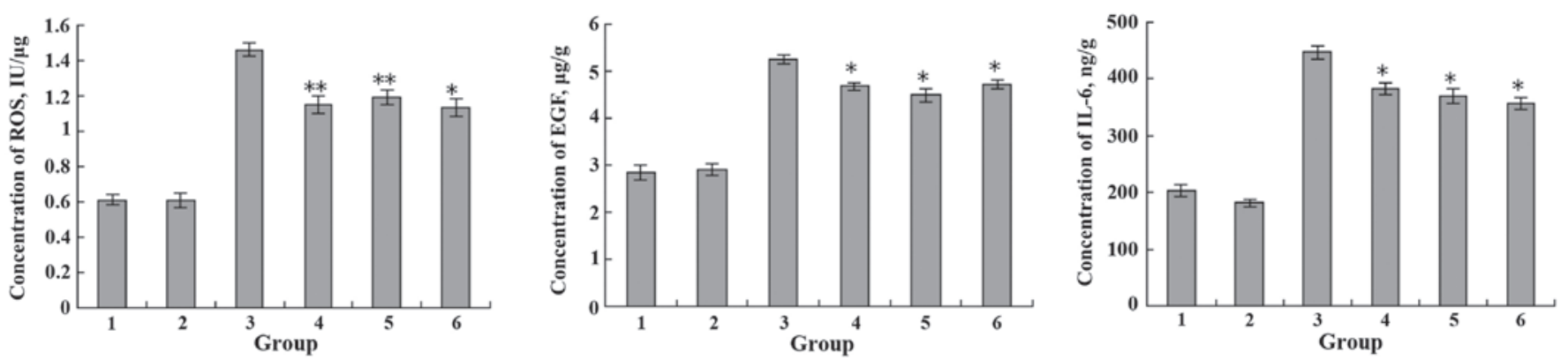

Figure 9. Effects of $\mathrm{Cu}^{2+}$ and DHA on the expression levels of ROS, EGF and IL-6. 1, blank group; 2, only DHA; 3, only $\mathrm{Cu}^{2+} ; 4, \mathrm{Cu}^{2+}$ and DHA added simultaneously; $5, \mathrm{Cu}^{2+}$ injured followed by DHA repair; 6, DHA treatment followed by $\mathrm{Cu}^{2+}$ injury. ${ }^{*} \mathrm{P}<0.05 ;{ }^{* *} \mathrm{P}<0.01$. DHA, docosahexaenoic acid; ROS, reactive oxygen species; EGF, epidermal growth factor; IL-6, interleukin-6.
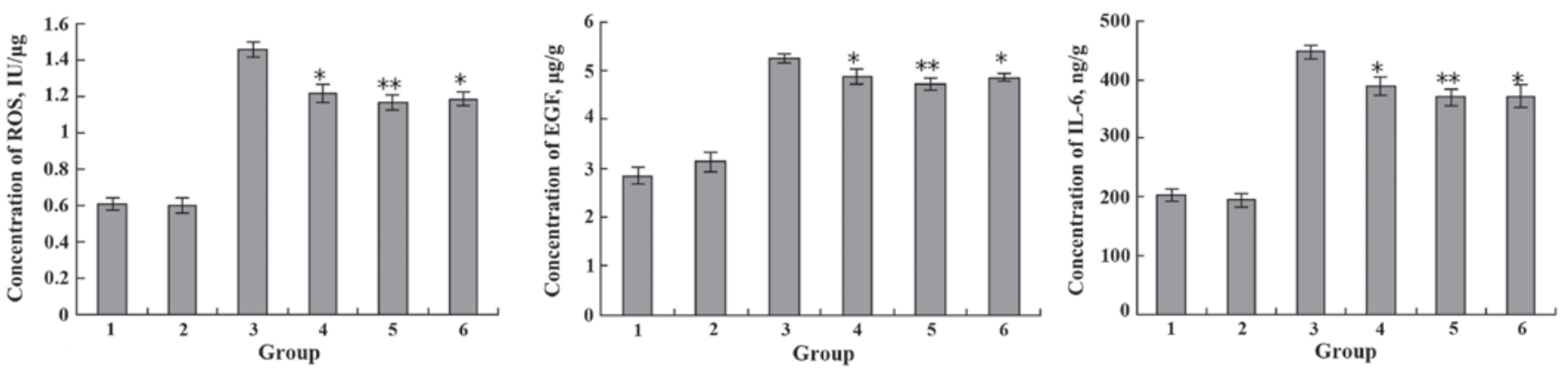

Figure 10. Effects of $\mathrm{Cu}^{2+}$ and EPA on the expression levels of ROS, EGF and IL-6. 1, blank group; 2 , only EPA; 3 , only $\mathrm{Cu}^{2+} ; 4, \mathrm{Cu}^{2+}$ and EPA added simultaneously; $5, \mathrm{Cu}^{2+}$-injured followed by EPA repair; 6, EPA treatment followed by $\mathrm{Cu}^{2+}$-injury. ${ }^{*} \mathrm{P}<0.05 ;{ }^{*} \mathrm{P}<0.01$. EPA, eicosapentaenoic acid; ROS, reactive oxygen species; EGF, epidermal growth factor; IL-6, interleukin-6.
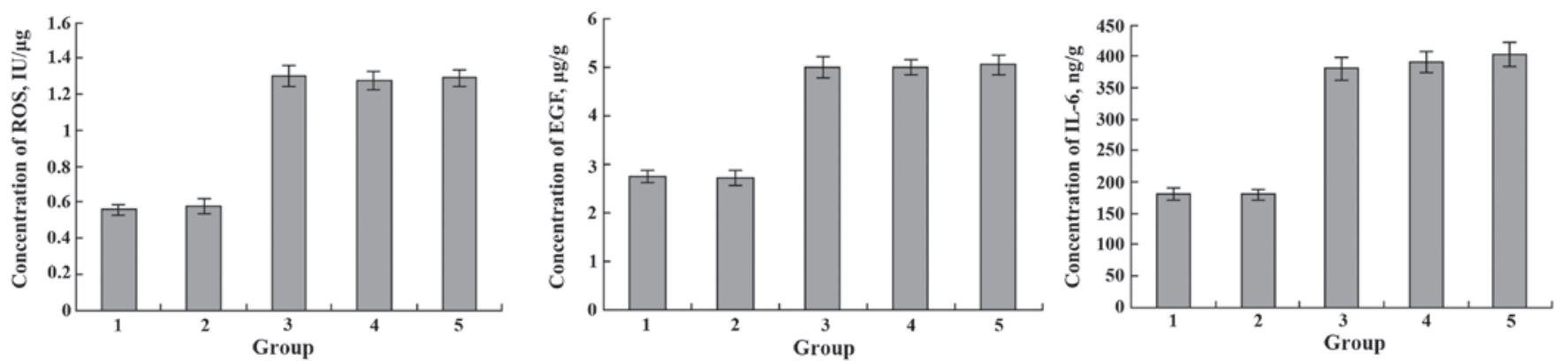

Figure 11. Effects of $\mathrm{Cd}^{3+}$ and DHA on the expression levels of ROS, EGF and IL-6. 1, blank group; 2, only DHA; 3, only Cd $\mathrm{Cd}^{3+} ; 4, \mathrm{Cd}^{3+}$-injured followed by DHA repair; 5, DHA treatment followed by $\mathrm{Cd}^{3+}$-injury. DHA, docosahexaenoic acid; ROS, reactive oxygen species; EGF, epidermal growth factor; IL-6, interleukin-6.

Effects of DHA and EPA on the ROS, EGF and IL-6 levels of IEC- 6 cells injured by $\mathrm{Pb}^{2+}$. Supplementation of DHA and EPA to IEC- 6 cells did not significantly affect the expression levels of ROS, EGF and IL-6 (P>0.05). Conversely, a substantial increase was observed as $\mathrm{Pb}^{2+}$ was added $\left({ }^{* *} \mathrm{P}<0.01\right)$ (Figs. 13 and 14). This result indicates that treatment with DHA and EPA induced a similar decrease in the content of ROS, EGF and IL-6 in $\mathrm{Pb}^{2+}$-injured IEC-6 cells.

\section{Discussion}

Heavy metal pollution is becoming increasingly serious and can cause a direct risk of harm to human health. Currently, exhaust fumes from automobile vehicles, industrial discharge, consumer waste and soil pollution are major sources of heavy metal pollution (14). Plants are heavy metal-contaminated through polluted soils; once animals have been fed with these contaminated plants, the animal carcasses and milk will be contaminated. The ingestion of those foods poses a severe health risks for humans (15). The heavy metals can accumulate in the human body through the food chain. As long as heavy metals have accumulated in living organisms, the body will be hard to degrade (16). Long-term exposure to heavy metals increases the risk of developing cancer, kidney failure, mental growth retardation and central and peripheral nervous system injury. There is substantial evidence supporting that the consumption of the $\omega-3$ PUFAs, EPA and DHA, are associated with health benefits. Despite increasing evidence of the beneficial effect of $\omega$-3 PUFAs, little is known concerning the effects of EPA and DHA on intestinal epithelial cells injured 

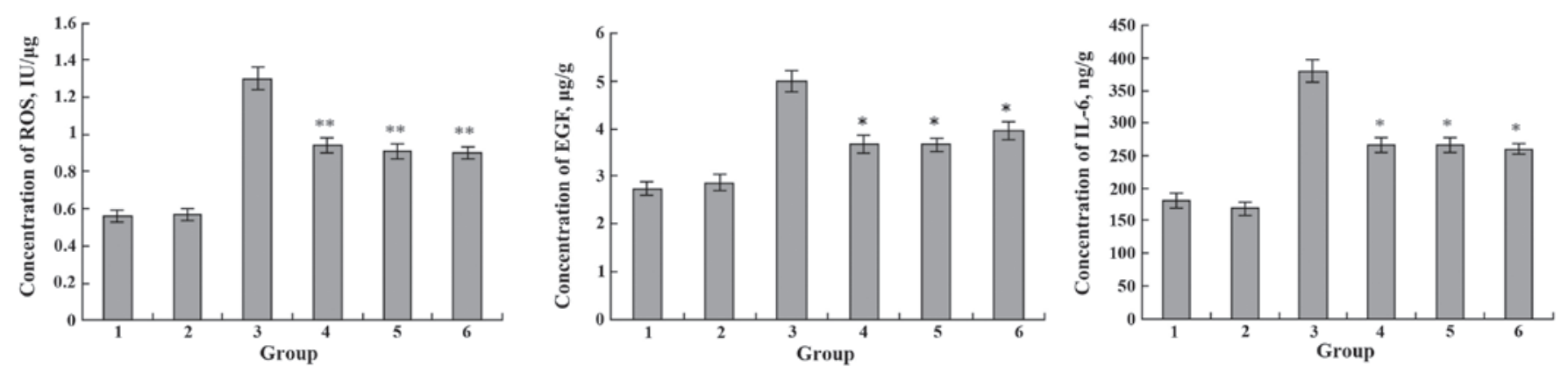

Figure 12. Effects of $\mathrm{Cd}^{3+}$ and EPA on the expression levels of ROS, EGF and IL-6. 1, blank group; 2 , only EPA; 3 , only Cd ${ }^{3+} ; 4, \mathrm{Cd}^{3+}$ and EPA added simultaneously; $5, \mathrm{Cd}^{3+}$-injured followed by EPA repair; 6, EPA treatment followed by $\mathrm{Cd}^{3+}$-injury. ${ }^{*} \mathrm{P}<0.05 ;{ }^{* *} \mathrm{P}<0.01$. EPA, eicosapentaenoic acid; ROS, reactive oxygen species; EGF, epidermal growth factor; IL-6, interleukin-6.
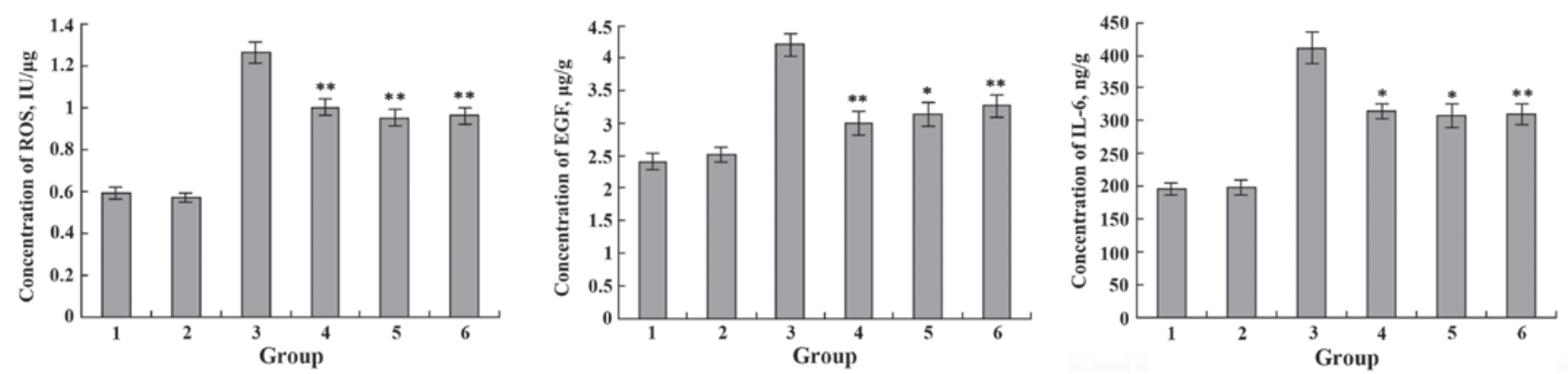

Figure 13. Effects of $\mathrm{Pb}^{2+}$ and DHA on the expression levels of ROS, EGF and IL-6. 1, blank group; 2, only DHA; 3, only $\mathrm{Pb}^{2+} ; 4$, $\mathrm{Pb}^{2+}$ and DHA added simultaneously; $5, \mathrm{~Pb}^{2+}$-injured followed by DHA repair; 6, DHA treatment followed by $\mathrm{Pb}^{2+}$-injury. ${ }^{*} \mathrm{P}<0.05 ;{ }^{* *} \mathrm{P}<0.01$. DHA, docosahexaenoic acid; ROS, reactive oxygen species; EGF, epidermal growth factor; IL-6, interleukin-6.
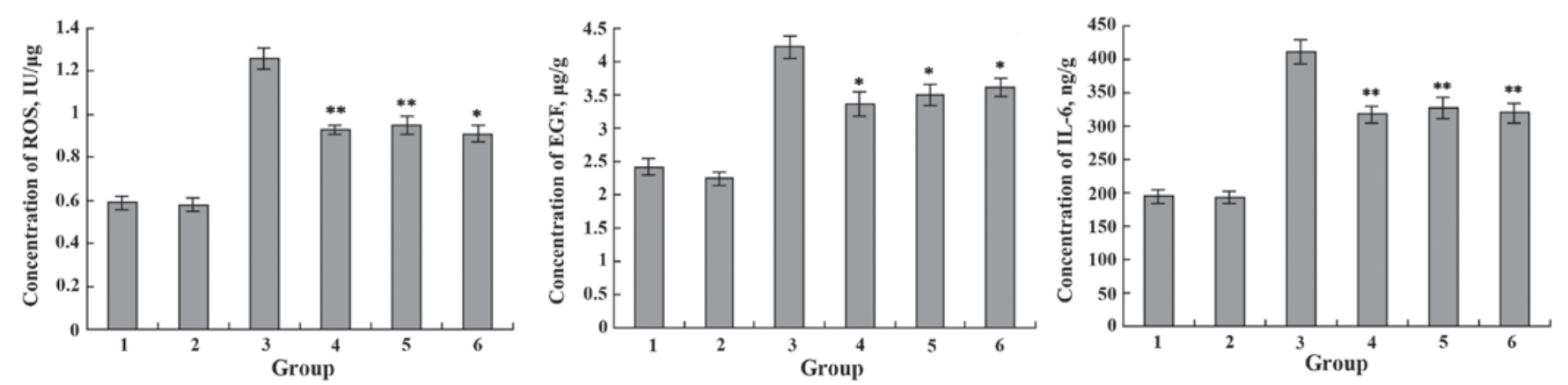

Figure 14. Effects of $\mathrm{Pb}^{2+}$ and EPA on the expression levels of ROS, EGF and IL-6. 1, blank group; 2, only EPA; 3, only $\mathrm{Pb}^{2+} ; 4, \mathrm{~Pb}^{2+}$ and $\mathrm{EPA}$ added simultaneously; $5, \mathrm{~Pb}^{2+}$-injured followed by EPA repair; 6, EPA treatment followed by $\mathrm{Pb}^{2+}$-injury. ${ }^{*} \mathrm{P}<0.05 ;{ }^{* *} \mathrm{P}<0.01$. EPA, eicosapentaenoic acid; ROS, reactive oxygen species; EGF, epidermal growth factor; IL-6, interleukin-6.

by heavy metals. The present study aimed to elucidate the effects of $\omega-3$ PUFAs (EPA and DHA) on the viability of intestinal epithelial IEC-6 cells exposed to heavy metals and the levels of ROS, EGF and IL-6.

The present results demonstrated that $\omega-3$ PUFAs could increase the percentage of IEC- 6 viable cells. The levels of ROS, EGF and IL- 6 of IEC- 6 cells injured by heavy metals increased, but decreased when EPA and DHA were administered. In addition, the $\omega-3$ PUFAs significantly reduced the expression level of ROS. The current studies generally support that ROS is inseparably associated with oxidative damage (17-19). The level of ROS increased when the IEC-6 cells were treated with the heavy metals; heavy metals may cause oxidative damage to cells, thus inducing the cells to secrete a large amount of ROS, which eventually triggers cell apoptosis and also increases the level of the inflammatory factors EGF and IL-6. Overall, the beneficial effects of DHA and EPA on damage caused by the heavy metals were observed in the present study.

The present data support the assertion that $\omega$-3 PUFAs could alleviate the adverse effects caused by heavy metal poisoning through improving the survival rates of intestinal crypt cell line (IEC-6). The results also suggest that $\omega-3$ PUFAs protected the IEC- 6 cells from the damage of heavy metals by reducing the expression levels of ROS, EGF and IL-6. In conclusion, $\omega-3$ PUFA supplementation is a promising direction to alleviate the damages caused by heavy metals. 


\section{Acknowledgements}

The present study was supported by the Health Bureau of Zhejiang Province (grant no. 2013KYA108) and Health and Family Planning Commission of Zhejiang Province (grant nos. 2013KYA108 and 2014KYA260).

\section{References}

1. Oszlánczi G,Papp A, Szabó A, Nagymajtényi L, Sápi A, Kónya Z, Paulik E and Vezér T: Nervous system effects in rats on subacute exposure by lead-containing nanoparticles via the airways. Inhal Toxicol 23: 173-181, 2011

2. Coen N, Mothersill C, Kadhim M and Wright EG: Heavy metals of relevance to human health induce genomic instability. J Pathol 195: 293-299, 2001.

3. Raghunath R, Tripathi RM, Kumar AV, Sathe AP, Khandekar RN and Nambi KS: Assessment of $\mathrm{Pb}, \mathrm{Cd}, \mathrm{Cu}$, and $\mathrm{Zn}$ exposures of 6- to 10-year-old children in Mumbai. Environ Res 80: 215-221, 1999.

4. Itariu BK, Zeyda M, Leitner L, Marculescu R and Stulnig TM: Treatment with $n-3$ polyunsaturated fatty acids overcomes the inverse association of vitamin D deficiency with inflammation in severely obese patients: A randomized controlled trial. PLoS One 8: e54634, 2013.

5. Itariu BK, Zeyda M, Hochbrugger EE, Neuhofer A, Prager G, Schindler K, Bohdjalian A, Mascher D, Vangala S, Schranz M, et al: Long-chain n-3 PUFAs reduce adipose tissue and systemic inflammation in severely obese nondiabetic patients: A randomized controlled trial. Am J Clin Nutr 96: $1137-1149,2012$

6. Spencer M, Finlin BS, Unal R, Zhu B, Morris AJ, Shipp LR, Lee J, Walton RG, Adu A, Erfani R, et al: Omega-3 fatty acids reduce adipose tissue macrophages in human subjects with insulin resistance. Diabetes 62: 1709-1717, 2013.

7. Simopoulos AP: Omega-3 fatty acids in inflammation and autoimmune diseases. J Am Coll Nutr 21: 495-505, 2002.

8. Belluzzi A: N-3 fatty acids for the treatment of inflammatory bowel diseases. Proc Nutr Soc 61: 391-395, 2002.

9. Clark WF, Parbtani A, Naylor CD, Levinton CM, Muirhead N, Spanner E, Huff MW, Philbrick DJ and Holub BJ: Fish oil in lupus nephritis: Clinical findings and methodological implications. Kidney Int 44: 75-86, 1993.
10. De Caterina R, Caprioli R, Giannessi D, Sicari R, Galli C, Lazzerini G, Bernini W, Carr L and Rindi P: n-3 fatty acids reduce proteinuria in patients with chronic glomerular disease. Kidney Int 44: 843-850, 1993.

11. Hall JC, Priestley JV, Perry VH and Michael-Titus AT: Docosahexaenoic acid, but not eicosapentaenoic acid, reduces the early inflammatory response following compression spinal cord injury in the rat. J Neurochem 121: 738-750, 2012.

12. Luchtman DW, Meng Q and Song C: Ethyl-eicosapentaenoate (E-EPA) attenuates motor impairments and inflammation in the MPTP-probenecid mouse model of Parkinson's disease. Behav Brain Res 226: 386-396, 2012.

13. Okabe N, Nakamura T, Toyoshima T, Miyamoto O, Lu F and Itano T: Eicosapentaenoic acid prevents memory impairment after ischemia by inhibiting inflammatory response and oxidative damage. J Stroke Cerebrovasc Dis 20: 188-195, 2011.

14. Jin X, Balasubramanian VV, Selvan ST, Sawant DP, Chari MA, Lu GQ and Vinu A: Highly ordered mesoporous carbon nitride nanoparticles with high nitrogen content: A metal-free basic catalyst. Angew Chem Int Ed Engl 48: 7884-7887, 2009.

15. He D, Qiu B, Peng JH, Peng L, Hu LX and Hu Y: Heavy metal contents and enrichment characteristics of dominant plants in a lead-zinc tailings in Xiashuiwan of Hunan Province. Huan Jing Ke Xue 34: 3595-3600, 2013 (In Chinese)

16. Quan SX, Yan B, Lei C, Yang F, Li N, Xiao XM and Fu JM: Distribution of heavy metal pollution in sediments from an acid leaching site of e-waste. Sci Total Environ 499: 349-355, 2014.

17. Polimeno L, Rossi R, Mastrodonato M, Montagnani M, Piscitelli D, Pesetti B, De Benedictis L, Girardi B, Resta L, Napoli A, et al: Augmenter of liver regeneration, a protective factor against ROS-induced oxidative damage in muscle tissue of mitochondrial myopathy affected patients. Int J Biochem Cell Biol 45: 2410-2419, 2013.

18. Labuschagne $\mathrm{CF}$ and Brenkman $\mathrm{AB}$ : Current methods in quantifying ROS and oxidative damage in Caenorhabditis elegans and other model organism of aging. Ageing Res Rev 12: 918-930, 2013.

19. Nzengue Y, Steiman R, Rachidi W, Favier A and Guiraud P: Oxidative stress induced by cadmium in the C6 cell line: Role of copper and zinc. Biol Trace Elem Res 146: 410-419, 2012. 